УДК 543.613.2 + 556.142

(C) 2012

Іваницька І. О., кандидат хімічних наук,

Сененко Н. Б., кандидат фізико-математичних наук,

Романович I. С., студент*,

Санжаревська О. I., студент

Полтавський національний технічний університет імені Юрія Кондратюка

\title{
ДОСЛІДЖЕННЯ СТАНУ ГРУНТУ ТА АРТЕЗІАНСЬКОЇ ВОДИ ПРИВАТНОГО СЕКТОРА М. ПОЛТАВА (РАЙОН ДЕНДРОПАРКУ)
}

\section{Рецензент - доктор технічних наук, професор В. О. Бондар}

Наведені результати комплексного експериментального дослідження проби трунту та основних фiзико-хімічних показників води децентралізованого водопостачання, відібраних у иеентрі м. Полтава (район Дендропарку). Виконаний аналіз впливу водорозчинної складової трунту на даний водоносний горизонт. На основі отриманих результатів та порівняння їх із нормативами, встановленими Держ.Сан.ПіНом, доведено, щзо досліджувана вода не відповідає фізіологічній потребі організму людини. Зроблені висновки про необхідність регулярного контролю якості та покращання стану грунту і питної води для використання їх населенням.

Ключові слова: трунт, децентралізоване водопостачання, фізико-хімічні показники, органолептичні показники, нітрат-іони, загальна твердість, вміст водорозчинних солей.

Постановка проблеми. Сучасний стан техногенного навантаження на довкілля спричиняє зміну режиму грунтових і підземних вод, поверхневого стоку, структури грунтів, інтенсифікацію ерозійних процесів у цілих регіонах, впливає на біогеохімічні процеси у літосфері, на зміни мікро- та макроклімату тощо. Грунт $\epsilon$ важливою і необхідною компонентою довкілля для нормального і повноцінного життя людини, - i саме 3 нього починаються всі процеси життєдіяльності та розвитку. Залежно від хімічного складу і характеру грунту змінюються рослинність місцевості, хімічний склад продукції рослинного й тваринного походження. Від нестачі або надлишку певних хімічних елементів у грунті залежить їх кількість у воді, рослинах, що порізному впливає на здоров'я населення. Поскільки значною мірою зросла кількість екзогенних хімічних і радіоактивних речовин у викидах в атмосферу та інших відходах промисловості, електростанцій, транспорту, проблема дослідження стану грунтів набула надзвичайної акту- альності не лише для сільської, а й для міської місцевості. Від фізико-хімічних властивостей грунту залежить формування складу грунтових $\mathrm{i}$ підземних вод, - мігруючи з грунту в середовища, що контактують із ним, хімічні речовини через харчові продукти, воду та іншими шляхами можуть впливати на організм і здоров'я людини.

Аналіз основних досліджень і публікацій, у яких започатковано розв'язання проблеми. Забруднення навколишнього середовища, насамперед, грунту і води, спричинило розпад, деградацію екологічних систем. Якість грунтових i підземних вод змінюється під впливом регіональних, локальних та лінійних джерел надходження компонентів забруднення. Серед регіональних джерел передусім слід згадати хімізацію сільськогосподарських угідь та окремі види водогосподарської діяльності, в тому числі невпорядковані звалища промислових i побутових відходів, склади мінеральних добрив й отрутохімікатів [12]. На території України виявлено 147 стабільних осередків забруднення підземних вод і експлуатується 93 великих (продуктивністю понад $5000 \mathrm{~m}^{3} /$ добу) водозаборів підземних вод, якість яких погіршилася внаслідок антропогенного впливу [7]. Відповідно до карти гідрологічного районування України, Полтавська область відноситься до Лівобережного Дніпровського району достатньої водності. Стан водних ресурсів області за інтегральним екологічним показником оцінюється як поганий [17]. Проблема забруднення питної води Полтавщини через незадовільний стан водопровідних споруд - $є$ нагальною навіть для централізованого водопостачання. Якість води децентралізованого водопостачання ще гірша, поскільки вода не проходить попередньої очистки перед споживанням.

* Керівник-кандидат фізико-математичних наук Н. Б. Сененко 
Причиною такого іï стану є передусім значна кількість відходів, що накопичилися в області. Крім того надмірне використання азотних добрив, - усі солі нітратної та нітритної кислот (нітрати та нітрити відповідно) є розчинними у воді, мігрують водоносними горизонтами на значні відстані, накопичуються у городині [16]. Найбільшу загрозу для людей і тварин становлять рослини, вирощені на грунтах, насичених нітратними добривами.

За кількістю випадків та масовістю отруєнь у світі рослини 3 підвищеним рівнем нітратів займають провідне місце. Крім того високонітратні продукти за систематичного їх вживання викликають так звану безсимптомну метгемоглобінемію [2]. Проблема забруднення води децентралізованого водопостачання приватного сектора м. Полтава нітрат-іонами, як і області в цілому, залишається наразі надзвичайно актуальною, особливо, коли навколо розташовані досить крупні промислові підприємства [3].

Метою роботи було експериментально визначити основні фізико-хімічні показники якості проб грунту, дослідити показники якості води децентралізованого водопостачання з артезіанської свердловини, яку населення використовує з питною метою; визначити вплив водорозчинної складової грунту на грунтову воду, оцінити наявність впливу забруднень грунту на водоносний горизонт даного водозабору і зробити можливі прогнози та рекомендації щодо покращання стану грунту та якості питної води.
Матеріали і методи досліджень. Проби води та грунту були відібрані відповідно до вимог стандартів [11, 13-15] у приватному секторі м. Полтава (район Дендропарку). Грунт інтенсивно використовується населенням із сільськогосподарською метою, а вода децентралізованого водопостачання вживається як питна. Нами були експериментально визначені відповідно до методик $[1,4-6,9,10]$ основні фізико-хімічні показники проб грунту й артезіанської води. Протягом комплексного дослідження грунту ми визначили його гігроскопічну вологість термостатичним та гідростатичним методами, вологоємність, густину, обмінну кислотність, вміст органічних речовин, $\mathrm{pH}$ водної витяжки, втрати маси при прожарюванні, вміст водорозчинних солей у водній витяжці грунту, визначили іiі макрокомпонентний склад. Окрім того провели якісний аналіз водної витяжки грунту 3 метою виявлення токсичних домішок. Виконали кореляційний аналіз одержаних результатів.

У ході дослідження проб води визначили органолептичні показники, основні фізико-хімічні показники та макрокомпонентний склад, порівняли одержані значення із санітарно-допустимими нормами.

Результати досліджень. Експериментально отримані результати представлені в таблиці 1.

\section{1. Фізико-хімічні показники якості грунту}

\begin{tabular}{|c|c|}
\hline Показник & Значення \\
\hline Вологість визначена термостатичним методом (\%) & 2,8 \\
\hline Вологість визначена гідростатичним методом (\%) & 2,9 \\
\hline Питома густина грунту $\left(г / \mathrm{cm}^{3}\right)$ & 2,56 \\
\hline Вміст кристалізаційної води (\%) & 1,21 \\
\hline Вологоємність грунту (\%) & 40,21 \\
\hline Вміст органічних речовин (\%) & 2,61 \\
\hline Вміст гумусу $(\%)$ & 2,35 \\
\hline Втрати маси при прожарюванні (\%) & 6,7 \\
\hline Вміст мінеральної частини грунту (\%) & 93,29 \\
\hline Обмінна кислотність (100 г. гр.), мг/ммоль·екв & $1,22 / 0,12$ \\
\hline рН водної витяжки грунту & 7,81 \\
\hline Загальний вміст водорозчинних солей (мг/100 г. гр.) & 108,3 \\
\hline Загальний вміст $\mathrm{HCO}_{3}^{-}$(100 г. гр.), мг/ммоль·екв & $50,9 / 0,835$ \\
\hline Загальний вміст CI' (100 г. гр.), мг/ммоль•екв & $36,836 / 0,549$ \\
\hline Загальний вміст $\mathrm{Ca}^{2+}(100$ г. гр.), мг/ммоль·екв & $13,446 / 0,671$ \\
\hline Загальний вміст $\mathrm{Mg}^{2+}$ (100 г. гр.), мг/ммоль·екв & $6,601 / 0,5432$ \\
\hline Загальний вміст $\mathrm{SO}_{4}{ }^{2+}(100$ г. гр.), мг/ммоль·екв & $8,2 / 0,1712$ \\
\hline Загальний вміст $\mathrm{Na}^{+}(100$ г. гр.), мг/ммоль·екв & $7,836 / 0,3408$ \\
\hline Загальний вміст $\mathrm{NO}_{3}{ }^{-}(100$ г. гр.), мг/ммоль•екв & $0,3 / 0,005$ \\
\hline Загальний вміст $\mathrm{Fe}^{3+}(100$ г. гр. $)$, мг/ммоль·екв & $1,53 / 0,085$ \\
\hline
\end{tabular}


2. Основні фізико-хімічні показники якості води

\begin{tabular}{|c|c|c|}
\hline Загальна характеристика & Проба води & Норма \\
\hline рН & 2 & 3 \\
\hline Органолептичні показники: & 6,25 & $6,5-8,5$ \\
\hline Кольоровість (градуси) & 3,5 & $\leq 20$ \\
Запах (бали) & 0 & $\leq 2$ \\
Смак (бали) & 0 & $\leq 2$ \\
\hline Жорсткість (ммоль-екв/л): & 0,285 & $\leq 7$ \\
Загальна & 0,143 & \\
Магнієва & 0,142 & $\leq 3,5-6,5$ \\
Кальцієва & 5,10 & $\leq 1000$ \\
\hline Лужність (ммоль-екв/л) & 270,10 & $\leq 0,3$ \\
\hline Хлорид-іони (мг/л) & 800 & $\leq 11$ \\
\hline ВРС (мг/л) & 0,08 & \\
\hline Загальне залізо (мг/л) & 0,10 & \\
\hline Нітрат-іони (нітратний азот), & & \\
мг/л & &
\end{tabular}

Досліджуваний грунт відноситься до суглинків. Досить малий вміст органічних речовин корелює з низьким значенням обмінної кислотності. Обидва показники відповідають невеликій гігроскопічній вологості грунту, визначеної термостатичним та гідростатичним методами. Насторожує значна вологоємність, спричинена наявністю глинистих мінералів із розсувною кристалічною решіткою. Існує відповідна кореляція 3 малим значенням втрат маси при прожарюванні. Реакція водної витяжки є слабо лужною, що добре корелює 3 макрокомпонентним складом водної витяжки грунту. Грунт досить ущільнений (значення питомої густини сягає 2,56 г/ $\mathrm{cm}^{3}$ ). Чим більша питома густина, тим більший опір при фільтрації, що підтвердилося під час фільтрування. Загальний вміст водорозчинних солей незначний, що свідчить про незасоленість грунту. Це значення $є$ позитивним для грунту, який використовують із сільськогосподарською метою. Під час розтирання грунт змінюе колір із темно-сірого на сірий, добре подрібнюється, при зволоженні злипається у грудки. Водна витяжка грунту забарвлена у світло-жовтий колір, що пояснюється незначним вмістом гумінових сполук заліза (III). Світло-жовтий колір мінерального залишку після прожарювання грунту $є$ тому підтвердженням. Після проведення відповідних аналізів можна зробити висновок, що всі показники знаходяться в межах встановлених норм, тобто стан грунту можна охарактеризувати як задовільний. Водночас слід звернути увагу на його виснаженість і малу родючість, що є характерним для грунтів майже всіх районів Полтав- щини та областей України [3].

Дослідження якості питної води представлені в таблиці 2.

Ми визначили основні фізико-хімічні показники якості води й порівняли отримані результати з показниками головного нормативного документа: $\mathrm{pH}$ трохи нижчий за норму, це підкислення, ймовірно, $\epsilon$ результатом впливу крупних промислових підприємств - автоагрегатного і турбомеханічного заводів. Органолептичні показники не перевищують допустимих нормативів. Кількість хлорид-іонів відповідає санітарним нормам.

Стан досліджуваної питної води даного водоносного горизонту можна вважати задовільним, що $є$ унікальним явищем для води децентралізованого водопостачання, відібраної майже в центрі міста. Що ж до фізіологічної потреби людини, то вода не відповідає нормі за значенням загальної жорсткості. Це свідчить про те, що забруднюючі речовини досить великого центру не потрапляють у перші водоносні горизонти. Важливим $\epsilon$ й такий факт, що в промисловоіндустріальному місті ще існує куточок, а саме район Дендропарку, $з$ такими показниками, можливо саме лісозахисні смуги захищають грунт і воду від шкідливого впливу зовнішніх факторів.

\section{Висновки:}

1. Необхідно регулярно вимірювати $\mathrm{pH}$ водної витяжки грунту з можливими рекомендаціями щодо його вапнування.

2. Стан досліджуваного грунту можна вважати задовільним і придатним для використання із 
сільськогосподарською метою. Доцільно рекомендувати регулярно вносити органічні добрива для збагачення його гумусової частини.

3. Унікальним для Полтавщини $є$ факт існування грунту задовільного стану в обласному центрі, поблизу великих промислових підприємств.

4. Необхідно регулярно визначати $\mathrm{pH}$ питної води та перевіряти її макрокомпонентний склад.

5. У складі децентралізованої води не виявлено токсичних домішок, що також $є$ винятком для води першого та другого водоносних горизонтів

\section{БІБЛІОГРАФІЯ}

1. Бирюков Н. С. Методическое пособие по определению физико-химических свойств грунтов / Н.С. Бирюков, В. Д. Казарновский, Ю. Л. Мотылёв. - М. : Недра, 1975. - 177 с.

2. Вредные вещества в промышлености / М. В. Лазарев // Справочник для химиков. В трех томах. - Т. ІІІ. - Л. : Химия, 1977. - 608 с.

3. Голік Ю. С. Екологічна бібліотека Полтавщини / Ю. С. Голік, О. Е. Ілляш. - Випуск 1. - Полтава : Полтавський літератор, 2004. - 166 с.

4. ГОСТ 3351-74. Вода питьевая. Методы определения вкуса, запаха, цветности, мутности. - М. : Издательство стандартов, 1975. - 169 с.

5. ГОСТ 4011-72. Вода питьевая. Методы определения общего железа. - М. : Издательство стандартов, 1982. - 9 с.

6. ГОСТ 18826-73. Колориметрический метод определения нитратов с сульфосалициловым натрием. - М. : Издательство стандартов, 1974. $8 \mathrm{c}$.

7. Дорогунцов С. І. Природні ресурси: екологоекономічна оцінка / С. І. Дорогунцов, А. М. Муховиков, М. А. Хвесик. - К. : Кондор, 2004. $291 \mathrm{c}$.

8. ДСПіН. Вода питна. Гігієнічні вимоги до якості води господарчо-питного централізованого водопостачання. - К., 1999. - 20 с.

9. ДСТУ ISO 6058:2003 (ISO 6058-1984, ЮТ). Визначення кальцію. Титрометричний метод із застосуванням етилендіамінтетраоцтової кислоти. - К., 2004. -6 с.

10. ДСТУ ISO 6059:2003 (ISO 6059-1984, ЮТ). інших приватних секторів м. Полтава.

6. 3а значенням загальної жорсткості досліджувана вода не відповідає фізіологічним потребам людини, при постійному вживанні такої води 3 питною метою до людського організму не потрапляє необхідна кількість солей кальцію і магнію, що може стати причиною захворювань серцево-судинної системи.

7. Існує ймовірність захисту грунту і води від шкідливого впливу антропогенного забруднення за рахунок значної кількості лісових насаджень.

Визначення сумарного вмісту кальцію та магнію. Титрометричний метод із застосуванням етилендіамінтетраоцтової кислоти. - К., 2004 - 6 с. 11. ДСТУ 10.3.81-6-2001. Якість грунту. Відбір проб. - К. : Держспоживстандарт України, 2002. $-17 \mathrm{c}$.

12. Коваленко О. М. Нітрат-нітритна проблема та шляхи іï вирішення / О. М. Коваленко, А. І. Горобець, А. М. Кучук // Науч. зап. Харьковского института экологии и социальной защиты. - Х., 2002 - T. 2. - C. 3-13.

13. НСУ ДСТУ ISO 5667-1:2003. Якість води. Відбирання проб. Частина 1. Постанови щодо проекту програм проведення відбирання проб. К. : Держспоживстандарт України, 2004. - 17 с. 14. НСУ ДСТУ ISO 5667-2:2003. Якість води. Відбирання проб. - Частина 2. Постанови щодо методів відбирання проб. - К. : Держспоживстандарт України, 2004. - 9 с.

15. НСУ ДСТУ ISO 5667-11:2006. Якість води. Відбирання проб. - Частина 11. Постанови щодо відбирання проб підземних вод. - К. : Держспоживстандарт України, 2007. - 11 с.

16. Хмельницкий Г. А. Ветеринарная токсикология / Г. А. Хмельницкий, В. Н. Локтинов, Д. Д. Полоз. М. : Агропромиздат, 1987. - 318 c.

17. Яиик A. В. Водне господарство в Україні / А. В. Яцик. - К. : Генеза, 2000. - 456 с. 